\title{
Why Did Carlyle Fail to Buy Xugong? --- A Case Analysis from National Security Perspective
}

\author{
Chan-Ting $\mathrm{CHEN}^{1, \mathrm{a},{ }^{*}}$ \\ ${ }^{1}$ East China University of Political Science and Law \\ No. 555 Longyuan Road, Songjiang District, Shanghai, China \\ achenchanting@126.com \\ ${ }^{*}$ Corresponding author
}

Keywords: Foreign Investment, National Security, Carlyle, Xugong

\begin{abstract}
The article reviews Carlyle's attempted acquisition of Xugong, explains that the national security concern over the case is due to the business nature of Xugong, the amount of money involved in the case, and a blog article accusing fairness of the transaction price. It also argues that the enactment of the Provisions on the Takeover of Domestic Enterprises by Foreign Investors is an inevitable result of the development of foreign investment regulations in China, not a sudden appearance caused by the case. The article lastly points out that the case is a good lesson for foreign investors doing or planning to do business in China to do as Chinese do. It also suggests that Chinese government improve foreign investment national security review mechanism and the public should have more objective attitude to inbound foreign investment.
\end{abstract}

\section{Introduction}

Although it has been a decade since the Carlyle - Xugong case occurred, the case is still worthy of study. As the South Weekend, one of the most popular weekly newspapers, once commented, the case was destined to be one of the notable landmarks in modern history of Chinese economy. Since then we had a more rational attitude towards foreign investment. [1] Also, because the aborted transaction happened shortly after Chinese CNOOC's unsuccessful experience in U.S. market, and the Provisions on the Takeover of Domestic Enterprises by Foreign Investors (hereinafter referred to as Provisions) was promulgated within the review process conducted by the Ministry of Commerce (hereinafter referred to as MOFCOM), the transaction was widely believed as retaliation to U.S. investors. Nevertheless, it is improper to have this finding simply because of the coincidence of timing. The opinion may adversely affect investment relations between U.S. and China and encourage thoughts of revenge.

\section{Carlyle's Attempted Acquisition of Xugong}

When Xugong announced its intention to find a partner, it received offers from many foreign suitors, including private equity fund J.P. Morgan Partners and construction equipment maker Caterpillar Inc. Xugong finally decided to cooperate with Carlyle for the latter. Carlyle, instead of simply absorbing Xugong's brand and using the company to penetrate Chinese market, made an alluring cooperation plan. In its proposal, Carlyle articulated its cooperative target as assisting Xugong to go out and develop the global market. Carlyle promised to introduce executives from Grand Vehicle Works, a U.S. manufacturer of transportation products, and managers of some Carlyle-owned firms, to discuss how to expand Xugong's business in the Middle East and Southeast Asia. Also, Carlyle promised not to lay off employees or change the management team without consent from the Chinese partners. [2] Since two parties wanted to foster collaboration, they originally planned to wind up the deal within two years. [3] Unfortunately, this had not been the case.

Due to the huge pressure from the government and the public, with national security threats suspect, Carlyle and Xugong revised their original agreement in mid-October, 2006, reducing the transacted shares from $85 \%$ to $50 \%$ for about $\$ 230$ million. This would mean a $44 \%$ increase of the original 
bidding price. [4] Carlyle hoped that giving up majority control could secure MOFCOM's approval. But the adjustment failed to do so. The transaction parties therefore for the second time revised the agreement on March 16, 2007 to further reduce Carlyle's share percentage to 45\%, keeping Xugong as the controlling partner with 55\% stake. [5] They failed again to obtain central government's approval. Later, Xugong and Carlyle jointly announced to stop the transaction because of the expiration of their initial agreement. [6]

\section{Governmental Scrutiny and National Security Concerns of the Carlyle-Xugong Case}

The government actively involved in Carlyle-Xugong case. The governmental scrutiny of foreign investment is in accordance with the requirement of relevant regulations. The Majority of foreign investors, when doing business in China, will have to begin with the "planning approval" from the National Development and Reform Commission (the NDRC), followed by the "foreign investment approval" from the MOFCOM, and concluding with the "business establishment approval" from the State Administration of Industry and Commerce (the SAIC), and their respective provincial and municipal sub-entities. If state-owned assets are involved, the State-owned Assets Supervision and Administration Commission (the SASAC) must nod at the transaction. [7]

In current case, Xugong was a company owned by the SASAC of Xuzhou City and was a famous brand of Jiangsu Province. The Xuzhou government therefore was an ex officio supervisor of the transaction. Both the local and provincial government nodded at the transaction for it would benefit Xugong financially and strategically. [8] Because the transaction amount was about USD375 million, the case then need approval from the Central government. However, the transaction did not go smoothly when dealing with government at the national level. The central government found national security concerns of the case when Carlyle firstly bid for 85\% of Xugong with USD375 million. [9] Though the Carlyle-Xugong acquisition agreement later was revised twice, the transaction never approved by MOFCOM.

MOFCOM hesitated to nod at Carlyle's acquisition due to the sensitivity of the case. It was the first time for a foreign corporation to attempt to control a big Chinese state-run corporation. [10] Had it succeeded, it would have been the biggest foreign acquisition of a controlling stake in a leading state-owned enterprise in China at that time. In addition, Xugong is one of the country's biggest machinery manufacturers. Manufacturing is a national strategic industry, closely related to sovereign security. As a leader in China's machinery market, China could lose relevant technology to foreign counterparts if Xugong is sold to foreign corporations, which also will adversely affect China's economic security. [12]

\section{Patriotic Sentiment Aroused by Carlyle-Xugong Case}

Carlyle's attempted buying of Xugong was condemned by the public for the assertion saying that the state asset was sold cheaply. A direct reason for the media and public to pay special attention to the case was a blog article written by Wenbo Xiang, the executive president of heavy machinery maker Sany Corporation.

In June, 2006, Xiang wrote in his blog that "selling anything is fine, but selling out the country is wrong." [13] This statement stirred concerns over the potential national security impact of the transaction nationally. Xiang later expressed his willingness to offer $\$ 400$ million dollars to buy Xugong, which was \$25 million higher than Carlyle's bid. [14] Xiang told the media that Xugong worth more than $\$ 375$ million due to the corporation reputation and product market share in China's heavy industry market, and also the 17 billion annual revenue. [15] Xiang further disclosed that Xugong rejected a 3.198 billion offer from J.P. Morgan's, the biggest competitor of Carlyle. Xiang therefore claimed a conspiracy between Xugong and Carlyle.

Facing Xiang's accusation, Xugong defended actively. Xugong explained that the amount of offer was only one factor, and the corporation would take every aspect into consideration, including technical assistance, enterprise vision, brand reservation, etc. Carlyle thereby was the common choice of Xuzhou government and Xugong. Still, the public chose to support the opinion that selling 
Xugong to Carlyle was selling state assets cheaply, and condemnation ensued. These arguments finally alarmed Beijing. MOFCOM then summoned all relevant personnel, enquiring detailed issues of the case. It is not usual for Chinese government to hold hearings on corporation acquisitions, and shows the importance of the transaction in Beijing's agenda. [16]

Xiang's articles and the ensuing public opposition are the direct reason for the abortion of Carlyle-Xugong case. The nature of Xugong Corporation and the importance of the corporation in China's machinery industry are the major reason for national security concern. There might be some link between CNOOC's Unocal bid and Carlyle's Xugong bid, for both of these two cases are significant for China. The former was an important case of Chinese corporation's going abroad strategy, while the latter was then the biggest foreign corporation's investment in China. Yet it is wrong to think that the latter is caused by the former.

\section{Carlyle - Xugong Case and the Enactment of the Provisions}

Another reason for people to talk about the Carlyle - Xugong case is that the Provisions was promulgated during the process of the case. There is a criticism saying the Provisions was specifically made for blocking Carlyle and further similar foreign investors. The conclusion that Carlyle - Xugong Case is the major reason of issuing the Provision is far-fetched. The promulgation of a regulation is a gradual process, and could not happen overnight. The Interim Provisions on Mergers and Acquisitions of Domestic Enterprises by Foreign Investors (hereinafter referred to as Interim Provision) was a start of the journey to establishment of national security review. [17] It for the first time announces the national security review concept, and says that an investors may be asked to inform MOFCOM of the transaction when a government agency finds that there are important factors seriously impacting market competition, national economy, people's likelihood or state economic security.

Later, the Interim Measures for the Administration of Examining and Approving Foreign Investment Projects (hereinafter referred to as Interim Measures) regulates the procedure that foreign investors should follow when they are investing in Chinese market. It requires that foreign investment projects must "comply with the public interests and related anti-trust prescriptions of the State." [18] This implies that if a foreign investment threatens China's national security either by controlling the security-related industry or by controlling a relevant market to monopolize it, NDRC will prevent the transaction from being approved. The timing of the emphasis on economic security is due to China's accession to the World Trade Organization, opening itself up to the global market. [19]

The emergence of the Provisions, replacing its predecessor the Interim Provision, is due to the changed situation when the sharply risen cross-border M\&A transactions aroused a large scale of national security concerns. For example, a report released by SAIC in 2004 found that foreign corporations were "using their dominant roles in technology, brand recognition and capital and management to suppress competitors and maximize profits" from Chinese market and "carry[ing] out sweeping mergers and acquisitions to absorb their major competitors." [20] The Provisions accordingly asks stricter governmental supervision over foreign companies' acquisition of domestic enterprises. Therefore, the Provisions, although to some extent was catalyzed by Carlyle - Xugong case, largely reflects the evolvement of China's national security review system and the change of the Chinese market.

\section{Implication of the Carlyle - Xugong Case}

For foreign investors, Carlyle's failure experience of buying Xugong is a lesson. A senior researcher from MOFCOM once said that it was very important to know Chinese idea and public awareness when doing business in China. Carlyle uses its own way to do business in China, trying to buy the majority share of Xugong. The wrong strategy brought national security concern and received resistance from the public. More haste, less speed. The Carlyle - Xugong case might result differently if Carlyle started with acquiring a small portion of shares. With preliminary contact, Carlyle would be able to contribute Xugong's development, strengthen communication with Chinese 
government and quell public doubts. The initial positive feedback would help Carlyle to make a further strategy to cooperate with Xugong.

For Chinese legislators, the case puts forward a question as how to protect the national security in foreign investment booming era. The foreign investment national security review mechanism is a feasible and popular solution. The Provisions mimics CFIUS review, requiring transaction parties to file an application with MOFCOM if "any important industry" is involved, or if a transaction has or may have "an impact on the national security," and the transaction results in the transfer of the actual controlling power of a domestic enterprise. [21] This basic pattern was followed and developed by the Circular of the General Office of the State Council on the Establishment of Security Review System Regarding Mergers and Acquisitions of Domestic Enterprises by Foreign Investors, and is now considered to be written into the coming Foreign Invest Law of China.

Lastly, general public should remain objective to inbound foreign investment. The following decade will witness an influx of foreign investment, for China now is considered as one of the most popular host countries for many multinational corporations. There is no doubt that the influx of foreign capital will change the distribution of the current market to a certain extent. A number of Chinese companies, including some national brands, will be eliminated in the competition. It is the survival of the fittest. It is also normal phenomena for foreign acquirers to seek controlling interest in famous local brands. Chinese companies do the same thing when buying foreign assets. The media should objectively report foreign investors' buying of Chinese companies, avoiding stirring up public emotions. Countries all over the world have to open up for economic development, so is for China. Excessive emphasis on national security is not conducive to introducing foreign investment or to China's economic development.

\section{Summary}

In the eighth round of China - US strategic and economic dialogue, issues of promoting bilateral investment and reaching an agreement on negative list are the priorities. The pre-establishment national treatment to inbound foreign investment inevitably requires an effective foreign investment national security mechanism to secure country's safety and best interests in foreign investment domain. The Case of Carlyle - Xugong is an early trial of the notion of the review mechanism in China. It is a signal to foreign investors that national security is an important consideration for Chinese government when allowing foreign capital entering the domestic market. Since then, the country's national security mechanism has achieved great improvement. Still, both the released Foreign Investment Law of China (draft) and the bilateral interaction between China and U.S. indicate that further development of the mechanism is important and pressing.

\section{References}

[1][16] Tao Ma, The End of Carlyle's Acquisition of Xugong, information on http://www.infzm.com/content/8003, last visited on May 26, 2016.

[2][8] Yanzheng Lu \& Zhe Cheng, Carlyle Xugong: The Last Mile, information on http://finance.sina.com.cn/g/20060404/14482473197.shtml, last visited on Jun. 1st, 2016.

[3] SASAC Approved New Proposal, Carlyle-Xugong Is Waiting For MOFCOM's Approval, information on http://news.xinhuanet.com/fortune/2006-11/12/content_5318672.htm, last visited on Jun. 1st, 2016.

[4] Andrew Batson, Carlyle to Buy Less of Chinese Firm, the Wall St. J., Mar. 19, 2007, at C2.

[5] Andrew Batson \& Laura Santini, Carlyle Scales Back Planned Stake in China Firm, the Wall St. J., Oct. 18, 2006, at A12. 
[6] Guohong Zhou \& Yujie Yao, Carlyle-Xugong Failed to Get Approval, Xugong Solely Started to Restructure the Board, information on http://news.xinhuanet.com/fortune/2008-07/24/content_8763679.htm, last visited on May 25, 2016.

[7] Tarrant Mahony, Foreign Investment Law in China: Regulation, Practice and Context, Tsinghua University Press, 2015, pp. 119-120.

[9][11] China's Xugong Drops Equity Sale to Carlyle, information on http://www.chinadaily.com.cn/bizchina/2008-07/23/content_6870896.htm, last visited on Jun. 18, 2016.

[10] Andrew Batson \& Matthew Karnistschnig, China Plans System to Vet Foreign Deals for Security, Wall St. J., Aug. 26, 2008, at C1.

[12] Zhihong Wan, Carlyle Abandons Xugong Dream, information on http://www.chinadaily.com.cn/bizchina/2008-07/24/content_6873004.htm, last visited on Jun. 22, 2016.

[13] Wenbo Xiang, How Was Xugong Sold Off, information on http://blog.sina.com.cn/s/blog_487d2dfa01000421.html, last visited on Jun. 25, 2016.

[14] Xin Zhang, Wenbo Xiang: Sany Will Try Hard to Acquire Xugong, information on http://finance.sina.com.cn/stock/s/20060821/12452840642.shtml, last visited on May. 10, 2016.

[15] Sany Intervenes, 400 Million to Buy Xugong technology, information on http://finance.sina.com.cn/stock/t/20060613/0000741041.shtml, last visited on May 30, 2016.

[17] Cathleen Hamel Hartge, China's National Security Review: Motivations and the Implications for Investors, 49 Stan. J. Int'1 L. 239, at 244.

[18] Interim Measures for the Administration of Examining and Approving Foreign Investment Projects, Article 12 Clause 3.

[19] Zhengxin Huo, A Tiger Without Teeth: The Antitrust Law of the People's Republic of China, 10 Asian-Pac L. \& Pol'y J. 32, 60 (2008).

[20] Cathleen Hamel Hartge, China's National Security Review: Motivations and the Implications for Investors, 49 Stan. J. Int'1 L. 239, at 245-246.

[21] Provisions on the Takeover of Domestic Enterprises by Foreign Investors, Article 12. 